\title{
Click Chemistry to Probe Hsp90: Synthesis and Evaluation of a Series of Triazole Containing Novobiocin Analogues
}

\author{
Laura B. PetersonBrian S. J. Blagg \\ Department of Medicinal Chemistry, The University of Kansas, 1251 Wescoe Hall Drive, Malott \\ 4070, Lawrence, KS 66045-7582, United States
}

\begin{abstract}
A series of triazole-containing novobiocin analogues has been designed, synthesized and their inhibitory activity determined. These compounds contain a triazole ring in lieu of the amide moiety present in the natural product. The anti-proliferative effects of these compounds were evaluated against two breast cancer cell lines (SKBr-3 and MCF-7), and manifested activities similar to their amide-containing counterparts. In addition, Hsp90-dependent client protein degradation was observed via western blot analysis, further supporting a common mode of Hsp90 inhibition for both structural classes.
\end{abstract}

\section{Keywords}

Hsp90; Novobiocin; Antiproliferation; Triazole

\begin{abstract}
Current cancer therapy strategies utilize the administration of multiple drug regimens that aim to halt multiple malignant processes simultaneously. Heat shock protein 90 (Hsp90) represents an exciting target for the treatment of cancer, as inhibition of this chaperone can affect multiple proteins that are directly associated with all six hallmarks of cancer. ${ }^{1-4}$ Hsp90 is a $90 \mathrm{kDa}$ molecular chaperone and is intimately involved in the post-translational conformational maturation of nascent polypeptides as well as the re-folding of denatured proteins and the re-solubilization of protein aggregates.5 Pharmacological inhibition of Hsp90 effectively inhibits protein substrates dependent upon Hsp90 for conformational maturation, resulting in destabilization of the Hsp90-client protein heteroprotein complex, which leads to degradation of substrates through the ubiquitin-proteasome pathway.4, ${ }^{, 6-7}$ Many proteins associated with malignant progression; including steroid hormone receptors, transcription factors and protein kinases, rely upon $\mathrm{Hsp} 90$ to reach their biologically active, three-dimensional conformation. As such, Hsp90 has emerged as a promising anti-cancer target, with more than 20 clinical trials currently in progress with small molecules that bind the N-terminal ATP binding site. ${ }^{8}$
\end{abstract}

The Hsp90 protein folding machinery requires co-chaperones and partner proteins to aid in the topological reorientation of polypeptide substrates. ${ }^{7}$ This protein folding process is ATPdependent, with hydrolysis occurring at the $\mathrm{N}$-terminal nucleotide binding site of the Hsp90

() 2010 Elsevier Ltd. All rights reserved.

*bblagg@ku.edu.

Publisher's Disclaimer: This is a PDF file of an unedited manuscript that has been accepted for publication. As a service to our customers we are providing this early version of the manuscript. The manuscript will undergo copyediting, typesetting, and review of the resulting proof before it is published in its final citable form. Please note that during the production process errors may be discovered which could affect the content, and all legal disclaimers that apply to the journal pertain. 
homodimer.9 All Hsp90 inhibitors currently in clinical trials bind this region. Although promising data has emerged from these trials, many of these compounds exhibit undesired toxicity and/or complicated dosing schedules. In contrast, the development of Hsp90 inhibitors that target other small molecule binding regions, such as that contained in the Cterminus remains minimally investigated.10 For example, novobiocin was shown to bind the C-terminus of Hsp90 in 2000 and provided the first example of a small molecule binding site outside of the $\mathrm{N}$-terminus. $11^{-12}$ However, novobiocin manifests only modest inhibitory activity $(500 \mu \mathrm{M})$. Since 2000 , other inhibitors of the C-terminus have also been identified, but the development of such compounds has not been thoroughly sought after. ${ }^{10}$

Since the discovery of the Hsp90 C-terminal binding site, analogues of novobiocin have been synthesized and evaluated, with many of the compounds manifesting micromolar antiproliferative activities. $13^{-17}$ Modifications to both the coumarin core and benzamide side chain have been pursued, resulting in the production of preliminary structure-activity relationships (SAR). The hydrogen bonding capabilities and the geometry of the amide bond appear to be important for novobiocin binding, however modifications to this moiety have not been fully realized to evaluate SAR. It was proposed that inclusion of 1,2,3-triazoles as a bioisosteric replacement for the amide moiety could facilitate SAR analysis for the aryl side chain by utilizing "click" chemistry. The triazole serves as a bioisostere due to similarities in both electronic and spacial characteristics to the amide bond. In addition, it is metabolically stable to hydrolysis and easily incorporated into small molecules. ${ }^{18-} 19$ In contrast, triazoles exhibit different hydrogen bonding capabilities and an altered geometry as compared to their amide counterparts, which aids in further elucidation of SAR. For these reasons, a series of 1,2,3-triazole containing novobiocin analogues was prepared. The design, synthesis, and biological evaluation of these compounds are described herein.

Synthesis of the 8-methyl coumarin core, as found in novobiocin, was commenced with commercially available 2-methyl resorcinol, $\mathbf{1}$ [Scheme 1]. Compound $\mathbf{1}$ was formylated under Vilsmeier-Haack conditions enlisting $\mathrm{POCl}_{3}$ and DMF, followed by hydrolysis to afford formyl-resorcinol $\mathbf{2}$. Similar to the procedure of Sivakumar and co-workers, condensation of $\mathbf{2}$ with $\mathrm{N}$-acetyl glycine in the presence of acetic anhydride, produced the bis-acylated coumarin, 3. ${ }^{20}$ Deacetylation of both the phenol and amine was accomplished upon heating with $\mathrm{HCl}$ and $\mathrm{EtOH}$ to afford 3-amino-7-hydroxy-8-methyl-coumarin, 4 . Conversion of amino-coumarin 4 to the azide, which was required for the copper-catalyzed Huisgen 1,3-dipolar cycloaddition, was accomplished by in-situ generation of the 3diazonium salt upon treatment with sodium nitrite in aqueous acid, followed by the addition of sodium azide to afford 3-azido-coumarin, 5a. ${ }^{20}$ Acetylation of coumarin $\mathbf{5 a}$ was accomplished with acetic anhydride in pyridine to afford $\mathbf{5 b}$.

Upon the generation of compounds $\mathbf{5 a}$ and $\mathbf{5 b}$, the copper-catalyzed Huisgen 1,3-dipolar cycloaddition with the corresponding alkynes was set to generate compounds 6-14a and 614b [Scheme 2]. Standard conditions were used to effect this transformation, and a combination of DMSO and $\mathrm{H}_{2} \mathrm{O}$ were found most suitable for optimal product formation. Alkynes 6-10 were chosen to investigate the electronic nature of the aryl side chain, including neutral (Me), electron withdrawing (F) and electron donating $\left(\mathrm{OMe}, \mathrm{NMe}_{2}\right)$ properties as originally identified during classical novobiocin SAR studies. ${ }^{13}$ Alkynes 11-14 were chosen based on prior observations that the analogous amide derivatives manifested good anti-proliferative activities against multiple cell lines, ${ }^{13}$ and thus provide direct comparison between amide and triazole analogues.

Completion of the triazole-containing novobiocin analogues was achieved by incorporation of the noviose sugar into 6-14a [Scheme 3]. The phenols of compounds 6-14a were noviosylated with the trichloroacetimidate of noviose carbonate (15) in the presence of 
boron trifluoride etherate. ${ }^{21}$ Solvolysis of the cyclic carbonate with methanolic triethylamine afforded novobiocin analogues 6-14c.

Upon preparation of compounds 6-14 a, $\mathbf{b}$ and $\mathbf{c}$, their growth inhibitory activities against MCF-7(ER+) and SKBr-3(ER-, HER2 overexpressing) breast cancer cell lines were determined [Table 1]. These results provide evidence that compounds $14 \mathbf{a}, 14 \mathbf{b}, \mathbf{1 4 c}$, and $11 \mathrm{c}$ are the most potent analogues prepared in this series. The structure-activity relationships suggest that analogues bearing sterically demanding side chains exhibit greater potency, as compounds with biaryl, indole, or homologated aryl groups (11-14) were more efficacious than substituted aryl compounds (6-10). In addition, comparison of compounds 6-10 suggests that para-substitution of the aryl ring with $\mathrm{Me}, \mathrm{OMe}, \mathrm{NMe}_{2}$ or $\mathrm{F}$ is not well tolerated, as these compounds displayed minimal anti-proliferative activity. These results suggest that the $\mathrm{C}$-terminal binding pocket has a large hydrophobic pocket that can easily accommodate substituents as in compounds 11-14.

Additionally, comparision between the amide containing analogues and triazole containing analogues provides further SAR [Table 2]. As evident from the data presented in Table 2, the triazole moiety has little effect on anti-proliferative activity. Both the triazole and amide analogues containing the biaryl and 3-indole side chains indicate the activities for both sets of compounds are comparable against the two cell lines tested. One discrepancy observed between the amide and triazole analogues is that in which simple aryl side chains $(\mathbf{6}-10)$ manifest $\mathrm{IC}_{50}$ values in the 10-20 $\mu \mathrm{M}$ range for the amide-containing molecules while the triazole compounds 6 and 9 display $\mathrm{IC}_{50}$ values above $50 \mu \mathrm{M} .{ }^{13}$ These results suggest that the triazole moiety affects biological activity in two ways: the availability of a hydrogen bond donor in the amide linkage and the steric bulk of the side chain. This hydrogen bond contact is lost upon introduction of the triazole moiety, but can be overcome by the introduction of steric bulk in the side chain. A preference for steric bulk has been observed in several series of novobiocin analogues, and appears to be a contributing factor to biological activity.

After analysis of the triazole containing analogues anti-proliferative activity, Western blot analysis was preformed for the most active compound, $\mathbf{1 4 b}$, to confirm anti-proliferative activity results from Hsp90 inhibition [Figure 2]. Western blot analysis of MCF-7 cells treated with increasing concentrations of $\mathbf{1 4 b}$, induce Hsp90-dependent client protein degradation in a dose-dependent manner, with an apparent $\mathrm{IC}_{50}$ value that correlates directly to the anti-proliferative $\mathrm{IC}_{50}$ value. Her2 and c-Raf are client proteins of $\mathrm{Hsp} 90$, and pharmacological inhibition of Hsp90 leads to their degradation via ubiquitinylation and proteome-mediated hydrolysis. Additionally, compound 14b appears to have little effect on the heat shock response, as unaltered levels of Hsp90 were observed, consistent with inhibition of the Hsp90 C-terminus. In contrast, client protein degradation and heat shock induction was not observed for the inactive compound 10b (data not shown). Western blot analysis indicates that these compounds are interfering with the Hsp90-mediated protein folding process, and that the anti-proliferative activities for these compounds are directly related to Hsp90 inhibition.

In conclusion, a series of triazole containing novobiocin analogues was prepared and evaluated against two breast cancer cell lines. Western blot analysis affirmed Hsp90 inhibition by this class of compounds. The compounds described herein exhibit comparable activities to the corresponding amide-containing analogues. These results indicate that the amide moiety can be replaced by the triazole functionality, however, in some cases the loss of the hydrogen bond donor appears detrimental, but can be overcome by the inclusion of steric bulk in the triazole substituent. 


\section{Supplementary Material}

Refer to Web version on PubMed Central for supplementary material.

\section{Acknowledgments}

The authors gratefully acknowledge the support of this project by NIH CA120458 and the NIH Training Grant (T32 GM008545) on Dynamic Aspects in Chemical Biology (L.B.P.).

\section{References}

1. Bishop SC, Burlison JA, Blagg BSJ. Curr. Cancer Drug Tar 2007;7:369.

2. Blagg BSJ, Kerr TD. Med. Res. Rev 2006;26:310. [PubMed: 16385472]

3. Hanahan D, Weinberg RA. Cell 2000;100:57. [PubMed: 10647931]

4. Zhang H, Burrows F. J. Mol. Med 2004;82:488. [PubMed: 15168026]

5. Soti C, Nagy E, Giricz Z, Vigh L, Csermely P, Ferdinandy P. Brit. J. Pharmacol 2005;146:769. [PubMed: 16170327]

6. Chiosis G, Vilenchik M, Kim J, Solit D. Drug Discov. Today 2004;9:881. [PubMed: 15475321]

7. Walter S, Buchner J. Angew. Chem. Int. Edit 2002;41:1098.

8. Biamonte MA, Van de Water R, Arndt JW, Scannevin RH, Perret D, Lee W. J. Med. Chem 2010;53:3. [PubMed: 20055425]

9. Prodromou C, Panaretou B, Chohan S, Siligardi G, O'Brien R, Ladbury JE, Roe SM, Piper PW, Pearl LH. EMBO J 2000;19:4383. [PubMed: 10944121]

10. Donnelly A, Blagg BSJ. Curr. Med. Chem 2008;15:2702. [PubMed: 18991631]

11. Marcu MG, Chadli A, Bouhouche I, Catelli MG, Neckers L. J. Biol. Chem 2000;2000:37181. [PubMed: 10945979]

12. Marcu MG, Schulte TW, Neckers L. J. Natl. Cancer Inst 2000;92:242. [PubMed: 10655441]

13. Burlison JA, Avila C, Vielhauer G, Lubbers DJ, Holzbeierlein J, Blagg BSJ. J. Org. Chem 2008;73:2130. [PubMed: 18293999]

14. Burlison JA, Blagg BSJ. Org. Lett 2006;8:4855. [PubMed: 17020320]

15. Burlison JA, Neckers L, Smith AB, Maxwell A, Blagg BSJ. J. Am. Chem. Soc 2006;128:15529. [PubMed: 17132020]

16. Donnelly A, Mays JR, Burlison JA, Nelson JT, Vielhauer G, Holzbeierlein J, Blagg BSJ. J. Org. Chem 2008;73:8901. [PubMed: 18939877]

17. Yu XM, Shen G, Neckers L, Blake H, Holzbeierlein J, Cronk B, Blagg BSJ. J. Am. Chem. Soc 2005;127:12778. [PubMed: 16159253]

18. Kolb HC, Sharpless KB. Drug Discov. Today 2003;8:1128. [PubMed: 14678739]

19. Tron GC, Pirali T, Billington RA, Canonico PL, Sorba G, Genazzani AA. Med. Res. Rev 2008;28:278. [PubMed: 17763363]

20. Sivakumar K, Xie F, Cash BM, Long S, Barnhill HN, Wang Q. Org. Lett 2004;6:4603. [PubMed: 15548086]

21. Shen G, Yu Xm, Blagg BSJ. Bioorg. Med. Chem. Lett 2004;14:5903. [PubMed: 15501066] 


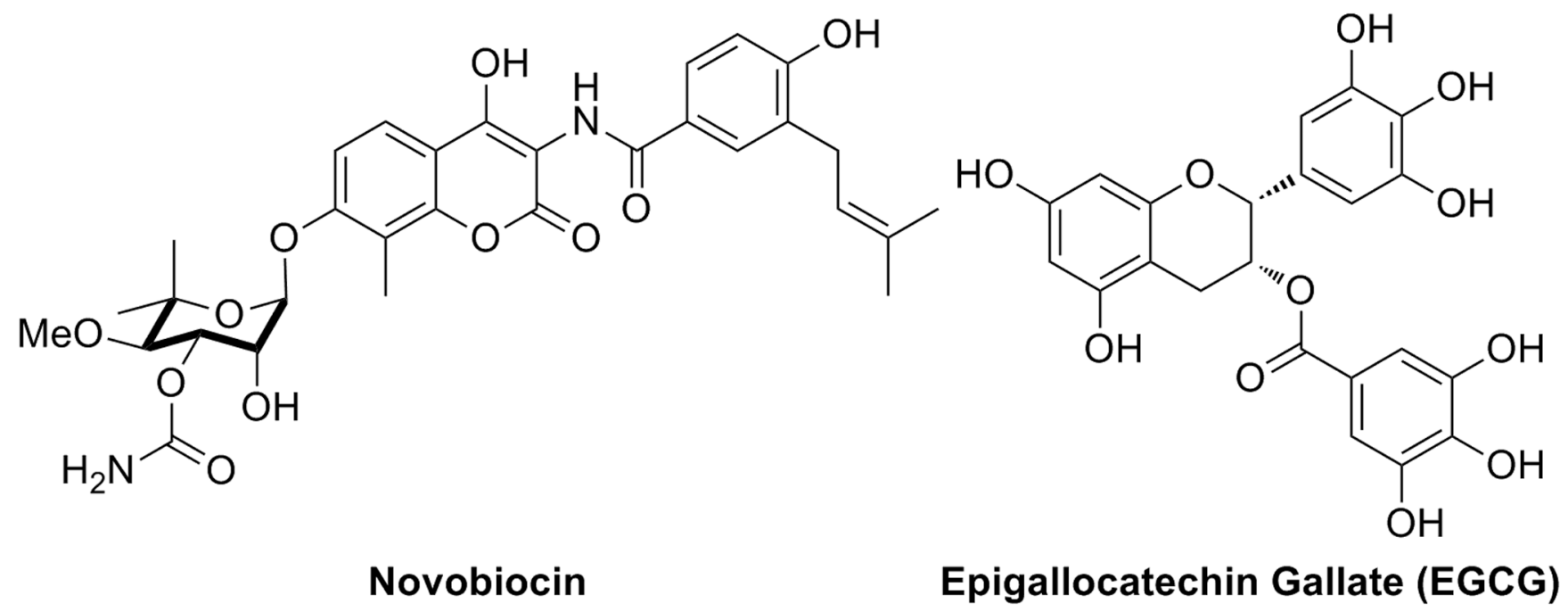

Figure 1.

Hsp90 C-terminal inhibitors 


\section{HM $\quad \begin{array}{llllll}1.0 & 5.0 & 10 & 50 & 100 & \text { GDA DMSO }\end{array}$ Her2}

\section{C-Raf}

\section{Hsp90}

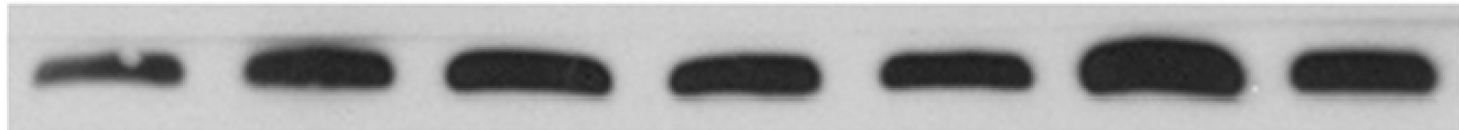

\section{Actin}

Figure 2.

Western blot analysis for compound $\mathbf{1 4 b}$ 
<smiles>Cc1c(O)cccc1Oc1ccc(C=O)c(O)c1C=O</smiles>

1

2

3<smiles>Cc1c(O)ccc2cc(N)c(=O)oc12</smiles>

4<smiles>[R]Oc1ccc2cc([N])c(=O)oc2c1C</smiles>

e

Scheme 1.

Reagents:(a) (i) $\mathrm{POCl}_{3}$, DMF, $\mathrm{MeCN}$; (ii) $\mathrm{H}_{2} \mathrm{O}$ (55\%); (b) $\mathrm{N}$-acetyl glycine, $\mathrm{NaOAc}, \mathrm{Ac}_{2} \mathrm{O}$; (c) $\mathrm{HCl}, \mathrm{EtOH}$ (d) $\mathrm{NaNO}_{2}, \mathrm{HCl}, \mathrm{EtOH}, \mathrm{H}_{2} \mathrm{O}$, then $\mathrm{NaN}_{3}$ (52\% 3 steps); (e) $\mathrm{Ac}_{2} \mathrm{O}$, pyridine, $\mathrm{CH}_{2} \mathrm{Cl}_{2}(>95 \%)$ 

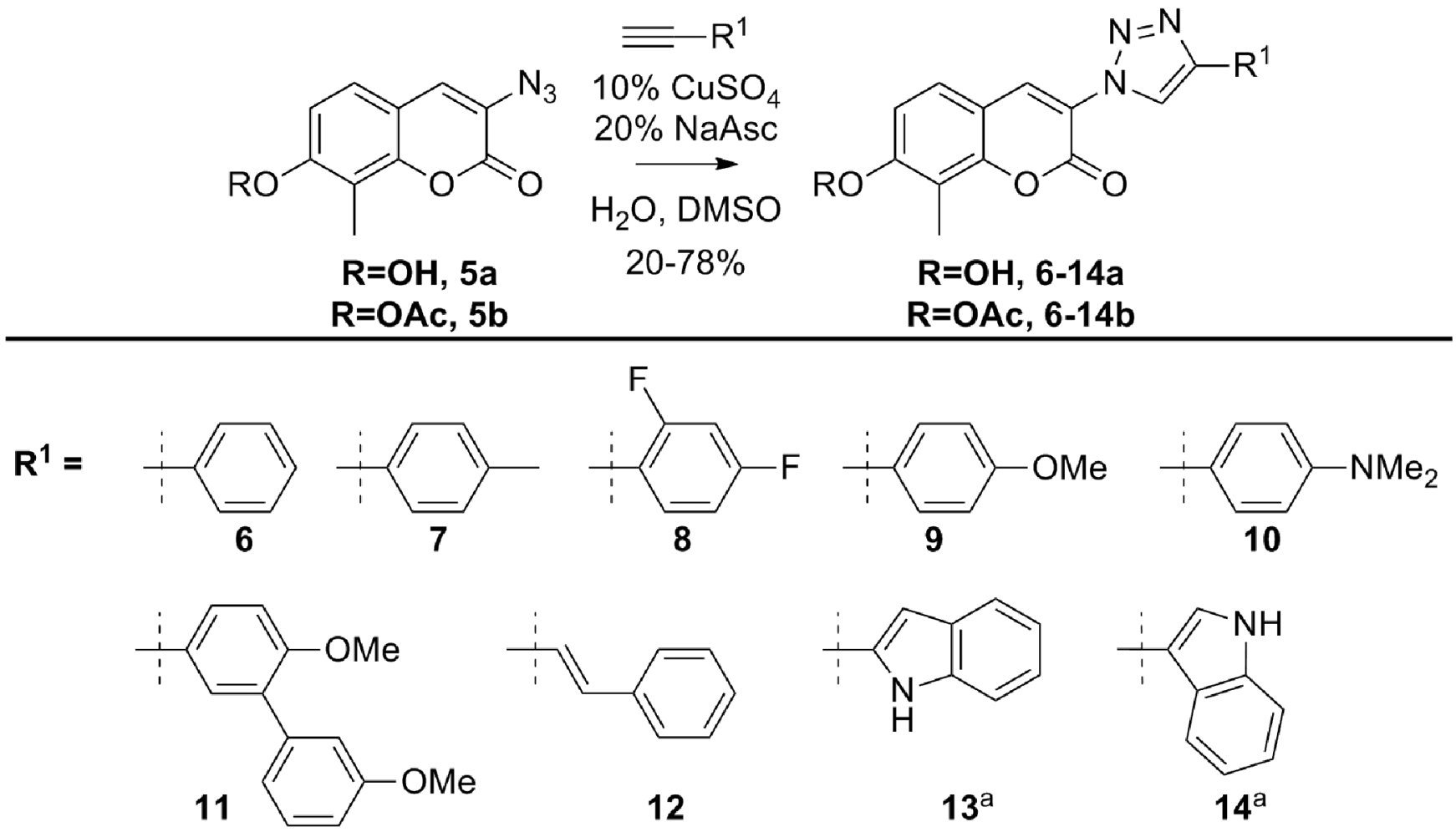

12<smiles>CC(C)(C)c1cc2ccccc2[nH]1</smiles>

$13^{a}$

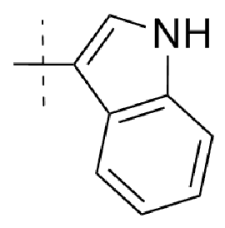

Scheme 2.

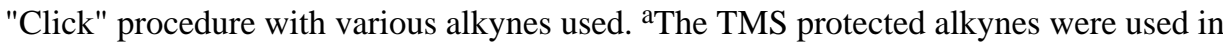
these reactions with the addition of 1 eq. TBAF 
<smiles>C=NN(C)c1cc2ccc(O)c(C)c2oc1=O</smiles>

$6-14 a$
1. 15

$\mathrm{BF}_{3} \bullet \mathrm{OEt}$
$\mathrm{CH}_{2} \mathrm{Cl}_{2}$

2. $\mathrm{MeOH}$ $\mathrm{NEt}_{3}$ $\mathrm{CH}_{2} \mathrm{Cl}_{2}$ $26-59 \%$

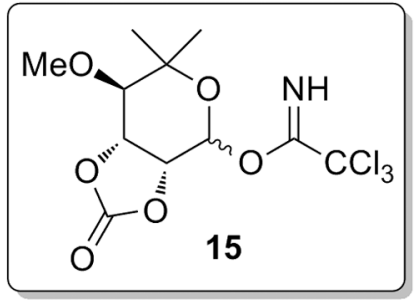<smiles>[R]c1cn(-c2cc3ccc(O[C@@H]4OC(C)(C)[C@@H](OC)[C@H](O)[C@H]4O)c(C)c3oc2=O)nn1</smiles>

$6-14 c$

Scheme 3.

Noviosylation of triazole appended coumarins. 
Table 2

Comparison of Anti-Proliferative Activies: Amide-Containing vs. Triazole-Containing Novobiocin Analogues

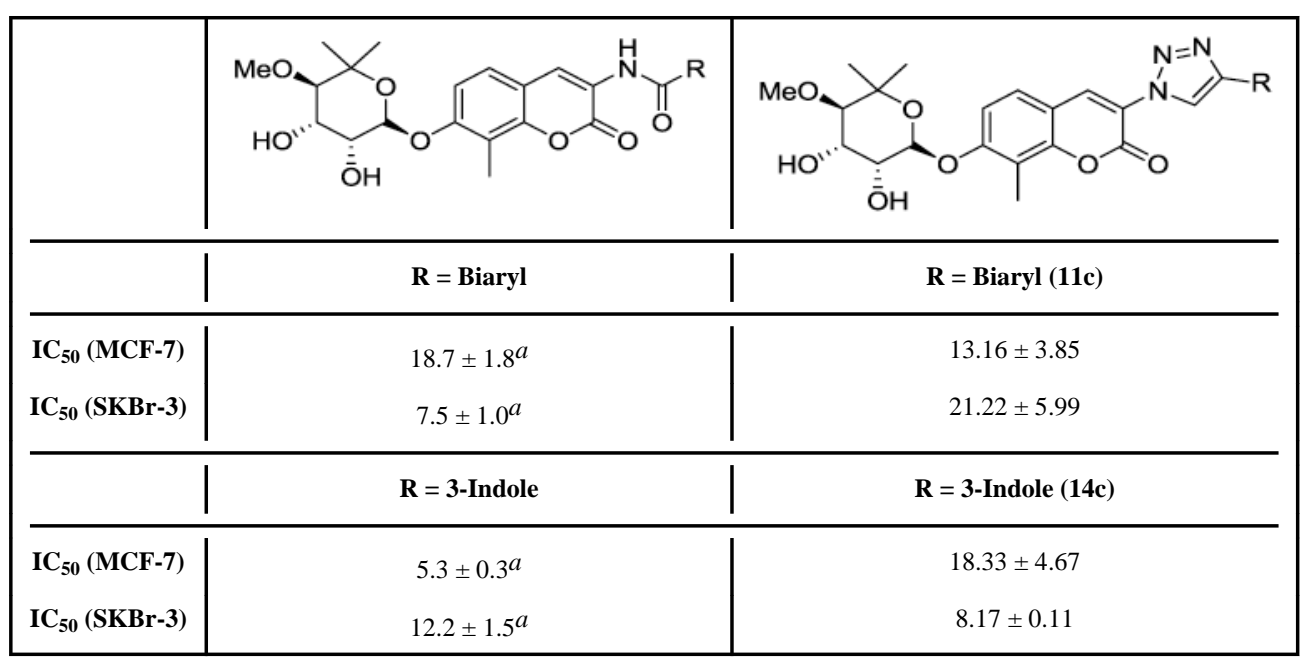

${ }^{a}$ Biological data taken from Ref. [13] 